\section{Umbilical cord thrombosis and chorioamnionitis in neonatal arterial ischaemic stroke}

A baby boy was delivered at term by emergency caesarean section because of abnormal fetal heart rate patterns during spontaneous labour. The umbilical cord arterial blood obtained at delivery had a $\mathrm{pH}$ of 6.97 and a lactate concentration of $12.1 \mathrm{mmol} / \mathrm{L}$. The Apgar scores were 3 and 7, respectively, at 1 and $5 \mathrm{~min}$. The proximal umbilical cord had a thrombotic aspect at delivery (figure 1). A thrombus was also identified in the ductus venosus at 1 hour of life. The boy presented left hemicorporeal seizures at 21 hours of life, which revealed a neonatal arterial ischaemic stroke (NAIS; figure 2). Placental histology revealed acute chorioamnionitis (online supplemental file). Screening for thrombophilia was negative in the boy and his mother. ${ }^{1}$

The pathophysiology of NAIS remains unclear but may be multifactorial. ${ }^{2}$ Two main mechanisms of NAIS are currently suspected: a cerebral embolism of a placental thrombosis and a focal cerebral arteritis secondary to chorioamnionitis. ${ }^{3}$ However, the intuitive embolic hypothesis is challenged, ${ }^{3}$ and perinatal inflammation is consistently reported as a major independent risk factor of NAIS in recent case-control studies. ${ }^{34}$

The baby combined a lot of NAIS risk factors: nulliparity, male sex, multiple markers of difficulty with transition-fetal heart rate abnormality, emergency caesarean section, low Apgar score, low umbilical artery $\mathrm{pH}$-and perinatal inflammation. ${ }^{2-4}$ Proximal umbilical cord thrombosis is highly unusual and has never been described in NAIS.

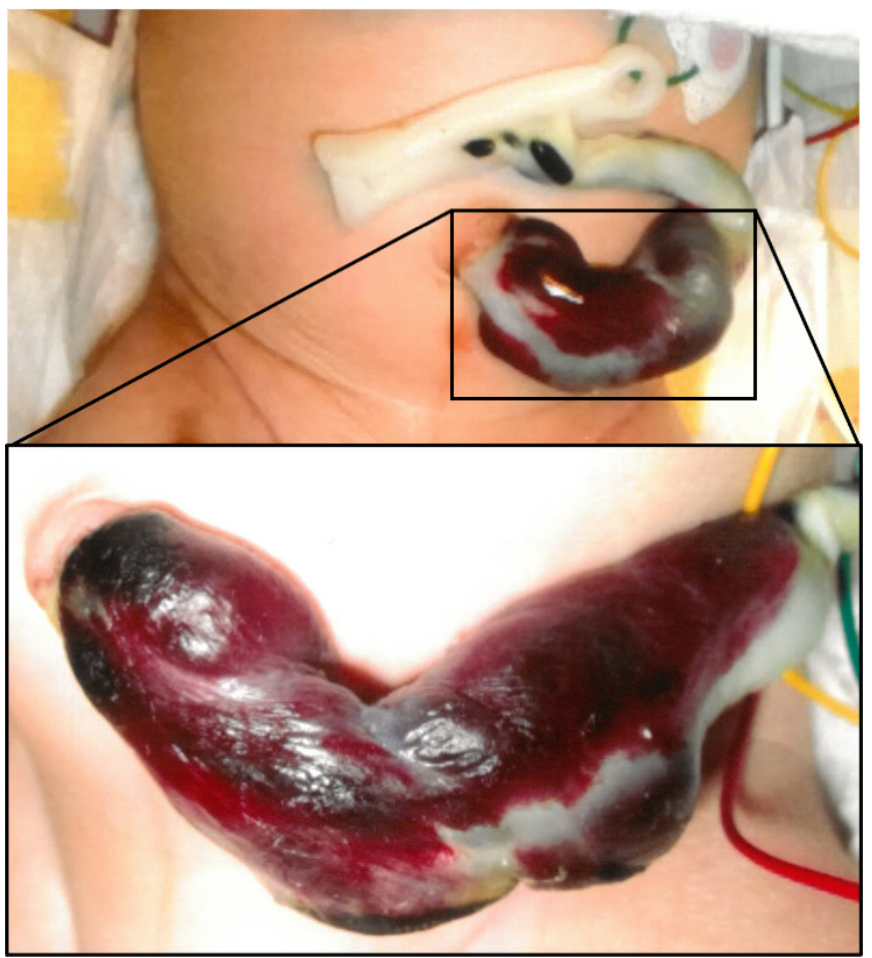

Figure 1 Umbilical cord at delivery.

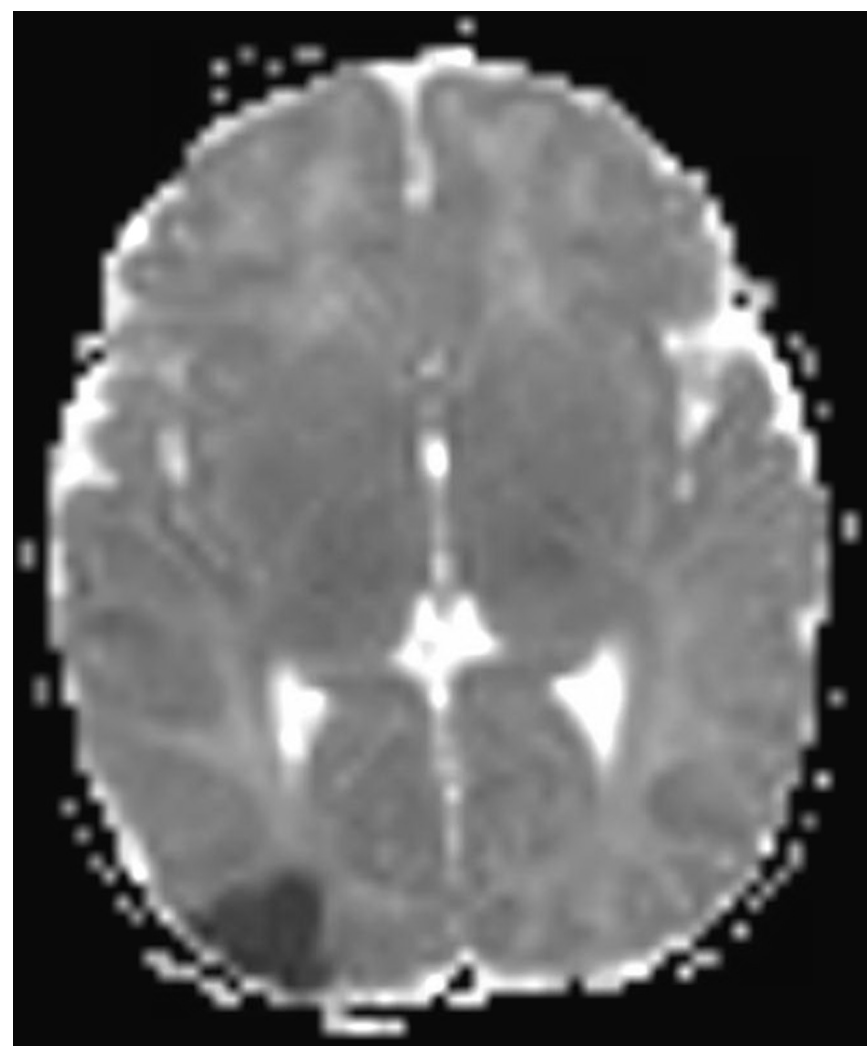

Figure 2 Focal restriction of diffusion on cranial MRI at 24 hours of life, delineating a recent ischaemic lesion in the superficial posterior territory of the right median cerebral artery.

Maroa Dridi, ${ }^{1}$ Stéphane Chabrier, ${ }^{2,3}$ Tiphaine Raia-Barjat, $^{3,4}$ Antoine Giraud $\circledast^{3,5}$

${ }^{1}$ Department of Pathology, Saint-Étienne University Hospital Center, Saint-Étienne, France

${ }^{2}$ French Center for Pediatric Stroke, Pediatric Physical Medicine and Rehabilitation, INSERM CIC1408, Saint-Étienne University Hospital Center, Saint-Étienne, France ${ }^{3}$ INSERM U1059 Sainbiose, Jean Monnet University, Saint-Étienne, France

${ }^{4}$ Department of Obstetrics, Saint-Étienne University Hospital Center, Saint-Étienne, France

${ }^{5}$ Neonatal Intensive Care Unit, Saint-Étienne University Hospital Center, SaintÉtienne, France

Correspondence to Dr Antoine Giraud, Neonatal Intensive Care Unit, SaintÉtienne University Hospital Center, 42055 Saint-Étienne, France; antoine.giraud@univ-st-etienne.fr

Contributors MD, TR-B and AG collected and analysed the data. MD and AG drafted the manuscript. SC and AG reviewed and revised the manuscript.

Funding Our work was supported by the Region Auvergne-Rhône-Alpes. Competing interests None declared.

Patient consent for publication Parental consent provided.

Provenance and peer review Not commissioned; internally peer reviewed.

Supplemental material This content has been supplied by the author(s). It has not been vetted by BMJ Publishing Group Limited (BMJ) and may not have been peer-reviewed. Any opinions or recommendations discussed are solely those of the author(s) and are not endorsed by BMJ. BMJ disclaims all liability and responsibility arising from any reliance placed on the content. Where the content includes any translated material, BMJ does not warrant the accuracy and reliability of the translations (including but not limited to local regulations, clinical guidelines, terminology, drug names and drug dosages), and is not responsible for any error and/or omissions arising from translation and adaptation or otherwise.

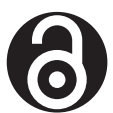

OPEN ACCESS 
Open access This is an open access article distributed in accordance with the Creative Commons Attribution Non Commercial (CC BY-NC 4.0) license, which permits others to distribute, remix, adapt, build upon this work non-commercially, and license their derivative works on different terms, provided the original work is properly cited, appropriate credit is given, any changes made indicated, and the use is non-commercial. See: http://creativecommons.org/licenses/by-nc/4.0/.

(C) Author(s) (or their employer(s)) 2021. Re-use permitted under CC BY-NC. No commercial re-use. See rights and permissions. Published by BMJ.

- Additional supplemental material is published online only. To view, please visit the journal online (http://dx.doi.org/10.1136/archdischild-2021-322143).

\section{D) Check for updates}

To cite Dridi M, Chabrier S, Raia-Barjat T, et al. Arch Dis Child Fetal Neonatal Ed Epub ahead of print: [please include Day Month Year]. doi:10.1136/ archdischild-2021-322143
Received 5 April 2021

Accepted 10 June 2021

Arch Dis Child Fetal Neonatal Ed 2021;0:F1-F2.

doi:10.1136/fetalneonatal-2021-322143

\section{ORCID iD}

Antoine Giraud http://orcid.org/0000-0003-2158-3930

\section{REFERENCES}

1 Curtis $C$, Mineyko A, Massicotte $P$, et al. Thrombophilia risk is not increased in children after perinatal stroke. Blood 2017;129:2793-800.

2 Dunbar M, Kirton A. Perinatal stroke: mechanisms, management, and outcomes of early cerebrovascular brain injury. Lancet Child Adolesc Health 2018;2:666-76.

3 Giraud A, Guiraut C, Chevin M, et al. Role of perinatal inflammation in neonatal arterial ischemic stroke. Front Neurol 2017;8:612.

4 Sorg A-L, von Kries R, Klemme M, et al. Risk factors for perinatal arterial ischaemic stroke: a large case-control study. Dev Med Child Neurol 2020;62:513-20. 